DOI: 10.17951/lrp.2018.37.2.91-103

\author{
LILIIA KOBYLIANSKA \\ Yurij Fedkovych Chernivtsi National University \\ ORCID: https://orcid.org/0000-0002-6872-9266
}

\title{
DEVELOPMENT OF THE CHILD'S PERSONALITY AS THE BASIC VALUE OF HOME EDUCATION
}

\begin{abstract}
Education in a post-industrial society serves a person as far as social and professional protection is concerned. It allows one to adapt to changes in life, to develop the mind and soul, or to reflect on the challenges of the new millennium. The humanistic values of education cause the change of the authoritarian-disciplinary model of tuition to the person-oriented one. It is important to turn knowledge into a personal value; to generate positive motivation; to deepen individualization in education. Education should be aimed at the development of the individual in all its diversity. The modern market of educational services in Ukraine is marked by diversity. Ukrainian education is trying to form a new generation of the national elite, reviving and introducing alternative models and forms of education by reforming the main links. Individual training and education among children occupies a special place. It is embodied in conditions of home (family) education.

Home education is a phenomenon of the social sphere of society, the main characteristic of which is the individualization of the upbringing and education of children in the family, carried out by parents or a specially invited teacher. It demonstrates the tendency to social interaction, the social mechanism for the development of family and public education. Home education solves social problems in an individual form, meets the consolidated requests of the family, its educational choice, as well as the needs of society and the states. Home tutorship is an educational system that implements the values of education through the unity of education and upbringing; comfortable interaction of the teacher with the child; use of advanced pedagogical technologies. The pedagogical potential of tutorship is the ability to provide an individual trajectory of the child's educational and personal development. Modern pedagogy is largely determined by the moral and spiritual values of the teacher, tutor, mentor, his world outlook, views of the world, moral attitudes. In the conditions of home (family) education, home teachers, teachers, tutors perform a number of social functions (socialization, adaptation, socio-cultural rehabilitation, etc.), as well as traditional duties - to teach, to educate, to enlighten, to develop.
\end{abstract}

Keywords: values of education, home education, individual approach, tutor, educational trajectory, development, personality, child 
For modern civilization, there is a diversity of values, among which education plays an important role. The global challenges of the $21^{\text {st }}$ century lead to a new understanding of education as a global value, designed to create a knowledgeable, moral and responsible person competent in the scientific fields and in the system of values. Education as a value unites three interrelated blocks: education as a state value, education as a social value and education as a personal value (Horshunski 1998, p. 34). The personal value of education is determined by motives and incentives in relation to a person and to the level and quality of his education.

From the beginning of education and throughout thousands of years of its implementation, it was predominantly individual and not a mass awareness of its value. Today, the leading educational trend in Ukraine and the world is a return to the personality-oriented education paradigm. This is a phenomenon of value anticipation, when, at a certain turn of the developmental spiral, a return to awareness of the value that was dominant in the lower turns occurs. Between the system of values, strategies and methods of education and upbringing, there is mutual dependence, that is, values determine their content. The renewal of the education system of Ukraine is based on the idea of abandoning the total unification and standardization of the educational and upbringing process. It should be flexibly modeled taking into account the individual traits of the subject - a child, a preschooler, a teenager, a schoolboy (Levchenko 2002, p. 444).

Based on the thesis of the uniqueness of each person, his personality traits, abilities, interests, life circumstances, the education system inevitably faces two problems. The first is the discrepancy between a certain part of students and the requirements of any single educational system. The second is the impossibility of creating a unified educational model that is optimal for all. Therefore, different forms of education are emerging that are alternative to mass schools.

Outside the mass school, there are possible forms of education: individual education, external studies and distance learning, which today encompasses about 6,500 children. In Ukraine, there is a big problem of getting education by children with disabilities. According to statistics, in 2015, there were 167 thousand disabled children in the country, 56.5 thousand of which were out of education. This is almost $2 \%$ of the total number of children's population of the country, their number increases by $0.2 \%$ per year.

Most of all children are on an individualized form of education, organized according to the position of the Ministry of Education and Science of Ukraine. The right to individual education is granted to different groups of children. First, students who, due to health reasons, cannot attend schools and children with high educational potential or underachievers. Secondly, students living in special conditions (highlands, in the zone of armed conflict, temporarily occupied terri- 
tory, etc.). The number of children enrolled in individual forms in the country's schools is growing. Only in Kiev for the period from 2013/2014 until 2015/2016, their number increased by almost $30 \%$ (from 1,568 to 2,014). 2,970 children involved in individual form of training in 2017 were in the Lviv region (http:// zik.ua/news/2017/04/24/). Children master the school curriculum for a separate curriculum, followed by teachers who teach them at home. Individual training is a positive way to optimize the content, methods and pace of training, make adjustments, and exercise control.

Gifted and underachieving students as a special group of schoolchildren can learn externally. Among the advantages of such a form of education one can find the ability to focus on certain subjects, to free the student from daily activities, to combine studies with other activities (e.g., art or sports). Traditionally, there are some shortcomings: lack of collective cooperation, limited influence of the teacher on educational activities. Distance learning (online and offline) is a form of external study, which requires considerable material resources and trained teachers. In addition, distance schools in Ukraine are institutions which are exceptionally private and the cost of training is quite high.

Home schooling is a way of getting education by teaching the child at home, without attending school. Home schooling was activated in the world at the beginning of the 1970s and today it is legalized in over 50 countries. It is especially popular in the USA, coordinated by the National Home Education Research Institute. In 2010, there were about 3 million home-educated pupils in the USA. Home schooling assumes that parents perform the functions of teachers or instructors. Austria, Australia, Belgium, Canada, Great Britain, Greece, Hungary, Italy, the United States of America, Finland, France are countries where home education has a legal status, while in Germany and Brazil such a form is considered as unacceptable, and in Sweden and China the reasons for introducing such a form of education are weighty (Shumaeva 2011, pp. 103-109).

Classical position: "personality is brought up by personality" provides the interaction of two personalities, cultural values and worlds - the child and the teacher. The mentor is called upon to solve a complex task: to meet the needs and demands of the individual and society, to be competitive in the market of educational services and at the same time to fulfill his mission of "the sower of the reasonable, kind, eternal" (Ohneviuk 2012, pp. 134-135). Changes in the social environment determine the requirements for training and personal qualities of a modern teacher. The centuries-old experience of pedagogical theory and practice, its best achievements, including the tutor system as a form of home (family) education, are being updated. Among scientists, there is no consensus on its effectiveness in modern conditions. However, the historical aspects of the 
phenomenon were investigated by N. Kovalevska, O. Korh-Cherba, E. Sarapulova, V. Stynska, S. Troshyna; the professional activities of the tutor were studied by A. Bogush, M. Holovko, S. Teplyuk, T. Tkachuk, O. Sharovatova, and others. The authors express different views on the problem, but do not deny the importance of its consideration in both theoretical and practical aspects.

\section{VALUE CHARACTERISTICS OF HOME EDUCATION: ADVANTAGES AND DISADVANTAGES}

The pedagogical values of education include: a person, his life, physical and mental health; the value of knowledge; value-motivational attitude towards the development of creative potential, opportunities and values-attitudes (Alexandrova 2009, pp. 16-23). Their basis is humanistic values as a positive activity-based active attitude towards man. It implies the observance of humanistic principles, the altruistic nature of feelings and experiences. This attitude is fixed in the corresponding actions, behavior of people; in resisting cruelty, evil, injustice; in a critical attitude towards oneself. In family education, which is organized by parents, they must be the natural bearers of these values. In the format of "home education" with the involvement of a specially trained teacher, educator, mentor, tutor, certain values are based on his professional abilities, knowledge, attitudes to activity.

The analysis of the value bases of home education provides for the identification of the reasons for the transition of parents to this form of education. The main thing is discontent with the existing system of secondary education in our country. It concerns the duration, complexity, material insecurity of schools, or vice versa, the high cost of education and the poor quality of its results. The state of children's health, lack of desire to go to school, an unfavorable psychological climate, conflicts with teachers and classmates are far from all reasons for abandoning the school. Parents emphasize that it is necessary to attract tutors to prepare for admission to university in the senior classes.

There are legal grounds for receiving home education in Ukraine. This concerns, above all, the responsibility of parents for the proper upbringing, education and development of the child. The Family Code of Ukraine, among the duties of parents, determines the upbringing and provision of a child with a general secondary education (Article 150), and among the rights is personal education, the right to choose forms and methods of education, except those that do not contradict the law and the moral principles of society (Kovalenko 2008, p. 13). The Law of Ukraine "On the Protection of Childhood" in Article 12 emphasizes the responsibility of parents for the upbringing, education and development of 
the child (Kovalenko 2008, p. 23). The Law of Ukraine "On Education" confirms the responsibility of parents for the upbringing, education and development of the child, in particular, to provide a full home education in accordance with the requirements for its content, level and scope (Article 59). Parents also have the right to choose an educational institution for underage children (Kovalenko 2008, pp. 31-32). In 1992, home education was legalized in Ukraine.

In 2016, active work was carried out to improve the Law of Ukraine "On Education". Several provisions are important for the legalization of home education. First, an individual form of education has been approved, which takes the form of an external, family (home) education and pedagogical patronage.

The family (home) form of getting education is a way of organizing the educational process for children (minors) by their parents or legal representatives independently for obtaining formal and/or informal education. The responsibility for this is borne by the parents. Pedagogical patronage is a way of organizing the educational process by pedagogical workers, provides for the assimilation of the educational program by a person who, because of a psychophysical state or for other reasons, requires this form.

Secondly, among the principles of state policy in the field of education and the foundations of educational activities directly related to family (home) education, the following are highlighted: human centeredness; quality of education and equal access to education; diversity of education; integration with the labor market; freedom in the choice of forms of education and types of education; humanism; democracy; public-private partnership (Article 6). Thirdly, one of the ways to legitimize the activities of home teachers/tutors is the provision of Article 52, which states that the participants in the educational process are: applicants for education; pedagogical, scientific-pedagogical and scientific workers; parents (legal representatives) other employees of the educational institution; individuals who carry out educational activities in the presence of a relevant license and other persons who are involved in the educational process. Such a legislative basis will allow the distribution of home education in accordance with the needs and rights of Ukrainian citizens.

The development of the child, his abilities is the main value of home education. It is expressed in tangible advantages, which distinguish scientists, parents, children. The main among them are:

- exercising the rights of parents to preserve beliefs, views, principles of family upbringing and education;

- individual approach to the child: the optimal schedule, pace, the amount of training, the choice of the form of employment, the selection of subjects, the opportunity to expand the educational environment of the child, that is, its own learning path; 
- psychological comfort: the choice of a mentor takes place taking into account the interests of the child;

- physical freedom of the child: release from the painful mode of training (calls, heavy schoolbag, etc.);

- emotional freedom of the child: absence of destructive conflicts between the mentor and the child, between the children; there is no peer pressure; increased self-rating;

- the child develops an individual style of education, and in the future life - an individual style of work that is highly valued by professionals; there is a motivation, independence and responsibility for the quality of their work, unconventional thinking;

- the positive atmosphere in the family, because a responsible attitude to the upbringing and education of children is a sign of healthy paternity.

As for the disadvantages of home education, they are concerned with the form in which parents are teachers. Scientists and parents argue that parents-teachers are not able to ensure the comprehensive development of the child. It is necessary to spend one's all time preparing and implementing the learning process. Children emphasize that there is increased control and hyper-care outgoing from parentsteachers. A child who studies at home has no experience in communication and interaction with peers and other people; "he lives in his own world" and does not have full social connections.

In modern Ukraine, in recent decades, tutorship has been enjoying a revival as a form of home education. This is promoted by certain reasons:

- the socio-economic development of society led to its stratification, the appearance of the middle class and a quite wealthy segment of the population seeks to give its children a better education;

- socio-cultural development, which requires its own national elite, which is traditionally formed not in mass educational institutions;

- the need to create a special atmosphere for development and special education for children with chronic diseases, limited opportunities, for gifted children, etc.;

- unemployment among specialists with higher education, the need for their training (retraining), obtaining a second higher education in order to obtain socially popular professions, among which - the profession of a tutor.

Home education is the need of individual citizens and society as a whole. It solves social problems in an individual form, it concentrates the family's requests, its educational choice. Such an alternative educational system is a socio-cultural mechanism for resolving the contradictions between freedom and the need for socialization of the individual. 
The professional market of services for tutors in Ukraine is still unprotected and undeveloped. O. Elnykova, the author of information systems and computer programs for school management and record keeping, developed her own concept of home teaching, in particular, with the involvement of tutors. According to Elnykova, the infrastructure of home schooling, is understood as the complex of interconnected structures, enterprises and markets that serve and ensure the realization of the child's education at home, or in private home schools (http:// education-ua.org/ua/). The researcher suggests to create a free exchange for the selection of cadres - tutors. They can be public, private, online or office. For their functioning, it is necessary to legalize the profession of the teacher and create their general state register. Tutors should, on general grounds, obtain a state license for pedagogical activity. Elnykova rightly emphasizes the importance of information resources of modern education. She suggests creating independent online ratings of teachers and home schools; creating in the Internet network training courses, projects; or placing important materials for tutors, parents and students.

Home education is a form of practical implementation of the basic human right to education. It must be guaranteed to all citizens of Ukraine, by their personal decision, without any restrictions in terms of education, age, gender, religious, racial or any other grounds. At the same time, such an education will not become a mass one, because a number of objective requirements are requested for its provision.

\section{HOME TUTOR/GOVERNESS AS THE CARRIER OF VALUES OF HOME EDUCATION}

Today, in the sphere of vocational education, there is a tendency for internally professional differentiation. This is a natural process of division of labor, which manifests itself not so much in grinding as in the development of more advanced and effective activities within the pedagogical profession. It is associated with the complication of the processes of education and training, which are determined by social changes (Slastenyn 2002, p. 14). The revival of the profession of a tutor in the system of home education is a manifestation of this trend.

The goals of home education are realized in the educational process. They are asked not only by the family, but primarily by the society, the state, and other social institutions. The goals of the educational process in a family environment can be divided into two groups. The first is the forming goals related to the tasks of translation and assimilation of experience for the development of certain social and personal achievements of the child (qualities, signs, attitudes, ways of thinking, adaptation and self-realization). The second group is developing values that 
allow free development and realization of the child's abilities and inclinations with different degrees of development, in a special social environment.

The humanistic pedagogical values of a home tutor/tutor consist of personal values; values of professional activity and values of pedagogical interaction. Personal values are based on the principles of humanism - the attitude to the child as the highest value, morality, tolerance, personal freedom, charity. Among the values of the professional activities of a tutor, the main ones are responsibility, competence, erudition, optimism, understanding of goals. Values of pedagogical interaction consist in perception of other people, tolerance, belief in the person, readiness for joint activity.

An important condition for effective work of a tutor is the setting of pedagogical activity, its orientation, that is, pedagogical goals. The setting is interpreted as readiness for activity, related to necessity. Professional-pedagogical attitude of teachers, including home teachers, is classified into productive and non-productive. The productive ones include self-centered (setting for success, self-education, self-development) and altruistic (setting love, respect, caring for their pupil). Unproductive ones are the attitudes to material well-being, the minimum costs in work, the escape from difficulties, the hidden need for power over the child, and the like. Professional attitude is the central link of the direction of the teacher. It is the pedagogical orientation - the characterization of the personality, the complex of individual qualities - that unites the system of ideals, interests and needs of the teacher, educator and tutor (Sergeev 2004, pp. 43-47).

Historical and pedagogical experience shows that in the system of governess education and training there were such types of specialists: nurses, nannies, home mentors, home teachers, uncles. Their name was determined by duties, age of children and professional status. Modern scientists have justified the terms: "tutor", "social tutor", "family social teacher", "tutor". The most controversial position is declared by E. Gordon, who believes that there is no hard difference between a tutor, a teacher, a preceptor, a home teacher, a mentor. Tutoring provides the academic, moral and philosophical development of an individual child and includes the following concepts: teacher, sophist, rhetorician, mentor, monitor, tutor and others (Gordon 2008, p. 279).

In our opinion, the term "tutor" is broader than the terms "home educator" or "home teacher". "Tutor" comes from the French gouvernante - "to manage". We affirm that the tutor is a special type of teacher who directs the child's development, manages the processes of education and upbringing on the basis of an individual approach and taking into account the abilities, inclinations, interests of children. Governess's activity is personally oriented, personalized; it can take place in individual or collective forms (if there are uneven-aged children in the 
family). It includes elements of education, upbringing, development and socialization of the individual; has specific tasks, content, methods, and it is informal and comfortable for all its participants (Kobylianska 2012, p. 18). We believe that the term "tutor" is a term that includes derivative dates determined by the specifics of the activities of specialists: the social governess, the family social teacher, the tutor, the home teacher, the home tutor, the social tutor.

E. Sarapulova identifies 14 psychological and pedagogical features of the teaching and upbringing activities of a home tutor. She argues that tutorship is an integral pedagogical system, a separate branch of pedagogy that studies the peculiarities of individual formation in the home conditions of an educated, harmoniously developed, communicative personality with an active life position (Sarapulova 2003, pp. 231-235). In the governess system, the unity of education and upbringing is traced - comfortable interaction of the teacher with the child; use of advanced pedagogical technologies. The content and results of the activities of the tutor must be adequate for the requirements of the society, educational institutions, parents and the child himself.

Values in the work of a tutor with a pupil are embodied through a personoriented approach, which manifests itself in the ability to create a favorable psychological atmosphere; to establish benevolent emotional communication; to favorably treat the child till it feels love, care and protection; to establish trust, cooperation with the pupil as an equal partner; to see the child's abilities and abilities; to provide activities, taking into account its interests (Hrytsiuk, Karataieva 2005, p. 249). Sarapulova believes that the educational function is leading in the activities of the tutor and offers

(...) a conditional system of modern education for home education. It consists of three directions: 1) "I - other people - society" (education of the child as an active conscious personality), 2) "I am a particle of nature" (ecological education of the child); 3) "I am a citizen of my state" (civic education) (Sarapulova 2003, p. 138).

Age features of the pupil are one of the most significant factors that determine the purpose of the tutor. The educational tasks for the child of preschool age is the formation of positive motivation for learning, basic educational skills, the development of the need for obtaining knowledge, the formation of interest in reading, the development of the child's creative forces, the formation of the ease behavior, the development of speech. Among the educational tasks, the most important are the formation of communication skills, the education of respect for elders, the love for parents, the development of interest in the profession of parents, learning the ability to empathize, the development of independence, and physical devel- 
opment. In the tutor-educator of a child of primary school age - in accordance with the values of activity - other tasks are singled out. This is the organization of the regime of the day: accompanying the child to and from the school; walks; educational games; control and help with homework; organization of visits to the theater, museums, exhibitions; pool, sports sections, additional institutions (music school, language courses). Development of personal abilities and inclinations of the child assumes different kinds of activity of the tutor. Among them there are teaching foreign languages, music, the basics of visual arts, dancing, methods of self-defense, alternative systems for hardening and physical development, teaching prestigious sports (tennis, figure skating, horseback riding), building technical skills and the like. The tutor always monitors compliance with the regime of work and rest, provides healthy and active leisure for the child, attracts him/her to physical education and sports, is responsible for life and health.

Achieving the goals of home education on the basis of the basic values of the activities of the tutor is facilitated by an individual program of work with the pupil. It provides the organization of individual lessons with the child, the variability of the use of educational literature and the form and location of the classes, creating favorable conditions for the individual development of the pupil; support the activities of a tutor and a pupil by family members (Grytsyuk, Karataeva 2005, p. 251). Culture and social orientation of the professional activities of the tutor will help to predict the results of the work, take responsibility for its content, forms and methods.

The institution of governess does not fully apply to either family or state forms of education, but is located on the border of these systems, and this is what attracts a significant part of the population. For tutorship, as a home education, the following are characteristic: the upbringing and education of children is individual; educational process at home; children perceive the tutor as both a teacher and a close person whose authority is not lower than the authority of parents (Sarapulova 2003, p. 84).

Governess as a bearer of the values of quality home education can ensure comprehensive and high-quality education, upbringing, socialization and development of certain groups of children. It contributes to the preservation of a harmonious family and educational environment. Its activities are based on the needs of an individual family and, at the same time, satisfy the demands of a significant part of society in the optimal combination of family and public education and training. There is nothing in human activity today that could not become the subject of a tutor's activity. Lack of strict regulation in activities, humanistic relations between the tutor, children and parents, long-term contact between the family, children and the tutor, the availability of broad opportunities for cooperation, create favorable conditions for the development of the pupil's personality. 
The purpose of modern education is the development of man as a person and the highest value of society, its talents, mental and physical abilities, the education of high moral qualities; a person who is socialized, creative, constantly changing, developing, open to the world. The state should provide mechanisms for the child to obtain the necessary knowledge in various educational environments. On the other hand, it is necessary to give parents the opportunity to choose a form of education that is comfortable for the child.

Home education has many advantages for both the child and the state. The child receives an individual approach to education, and the state can save money allocated for the maintenance of the student. In modern Ukraine, it is important to create a strategy for reforming the educational system, taking into account the realities of the $21^{\text {st }}$ century and accumulating adequate resources for carrying out reforms.

Educational realities stimulate the emergence, revival, approval of new forms of obtaining a quality education. Among them there is home education with the involvement of a specially trained specialist: home teacher, educator, mentor, and tutor. The range of its activities is determined by the specifics of professional training, the needs and requirements of the family, society, or state. The social purpose of the profession of a tutor is not limited only to the provision of individual services to a single, well-off family. Gouverner can realize the goals and values of home education in various educational environments close to family (for example, in private preschool institutions, in foster families and family-type children's homes); work as volunteers in public organizations that provide appropriate services to families where children with disabilities are being educated (Kobylianska 2012, p. 23). In addition, the conjuncture of the labor market in Ukraine indicates the need for such specialists.

Home tutorship is a purposeful activity aimed at preserving and developing physical and mental health; the development of one's creative abilities, the formation of a system of knowledge; moral and aesthetic education, the assimilation of social experience as the basis for the comprehensive development of the individual. Its goal is related to the development of children's natural needs, abilities, qualities necessary for survival in a constantly changing society that will ensure a painless entry into adulthood.

Restoration of the institution of governess in its new qualities can remain only an idea, a project, if we do not take into account the objective social conditions that determine its development. The most significant among them are:

- the development of education and culture in Ukraine in the $21^{\text {st }}$ century;

- state support (material, legislative, etc.) of innovations in education, including the tutor system of education and upbringing;

- the ability of each family to use their right to provide the child with the appropriate education; 
- creation of a system for training tutors;

- formation of a positive public opinion, associations of parents and specialists of home (family) education with the aim of establishing cooperation with state educational and upbringing institutions.

\section{REFERENCES}

Александрова, О.Ф., 2009, Гуманістичні педагогічні цінності майбутніх учителів як основа професійної діяльності. In: Збірник наукових праць. Класичного приват. ун-ту «Педагогика формування творчої особистості у вищій і загальноосвітній школах», № 4 (57).

Гершунский, Б.С., 1998, Философия образования для XXI века (В поисках практикоориентированных образовательных кониепиий). Москва: Совершенство.

Гордон, Э., 2008, Столетия тьюторства. Иже́вск: ERGO.

Коваленко, Є.І. (ред.), 2008, Енциклопедія батьківства. Київ: КНТ.

Єльникова, О. Домашнє навчання як альтернативна форма загальної середньої освіти, http://education-ua.org/ua/ [access: 19.02.2017].

Кобилянська, Л.І., 2012, Сучасні педагогічні технологї̈ підготовки майбутніх гувернерів. Чернівці: Чернівецький національний університет.

Левченко, T.I., 2002, Розвиток освіти та особистості в різних педагогічних системах. Вінниця: Нова Книга.

Грицюк, М.I., Каратаєва, М.І. (ред.), 2005, Нові форми здобуття дошкільної освіти. Тернопіль: Мандрівець.

Огневюк, В.О. (ред.), 2012, Освітологія: витоки наукового напряму. Київ: Едельвейс.

Сарапулова, Є.Г., 2003, Психолого-педагогічні основи навчально-виховної діяльності гувернера. Київ: МАУП.

Сергеев, И.С., 2004, Основы педагогической деятельности. Санкт-Петербург: Питер.

Сластенин, В.А., 2002, Педагогика. Москва: Академия.

Шумаєва, С., 2011, Навчання вдома як альтернатива формальній шкільній освіті: світовий вимір. «Порівняльно-педагогічні студії», № 1 (7). 


\title{
ROZWÓJ OSOBOWOŚCI DZIECKA JAKO PODSTAWOWEJ WARTOŚCI EDUKACJI DOMOWEJ
}

\begin{abstract}
Abstrakt: Celem edukacji w społeczeństwie postindustrialnym jest ochrona społeczna i zawodowa ludzi, co pozwala na dostosowanie się do zmian życiowych, rozwijanie umysłu i siły psychicznej oraz skłania do zastanowienia się nad wyzwaniami nowego tysiąclecia. Edukacja powinna być skierowana na rozwój osobowości we wszystkich jego aspektach. Rynek nowoczesnych usług edukacyjnych na Ukrainie cechuje różnorodność. Edukacja ukraińska próbuje tworzyć nową generację narodowej elity, ma na celu wprowadzenie alternatywnych modeli i form edukacji. Indywidualne szkolenie i kształcenie zajmują tu szczególne miejsce, a są realizowane w ramach edukacji domowej. Główną cechą tego typu edukacji jest indywidualizacja kształcenia i szkolenia dzieci w rodzinie, prowadzonego przez rodziców lub specjalnie zaproszonego nauczyciela. W jej efekcie uwypukliła się skłonność do interakcji społecznych, okazało się też, że ważny jest mechanizm społeczny rodziny oraz opieki społecznej i edukacji. Edukacja w domu rozwiązuje wiele problemów społecznych w indywidualnej formie. Należy dodatkowo wskazać na domową edukację guwernerską. Jest to system edukacyjny, który uwzględnia różne wartości edukacji poprzez: ujednolicenie kształcenia i szkolenia, wygodne współdziałanie nauczyciela z dzieckiem, wykorzystanie nowoczesnych technologii edukacyjnych. Pedagogiczny potencjał guwernerstva tkwi w zdolności do zapewnienia indywidualnej trajektorii edukacyjnej i osobistego rozwoju dziecka.

Nowoczesna pedagogika w dużej mierze zależy od moralnych i duchowych wartości nauczyciela, wychowawcy, mentora, jego poglądów na świat i przyjmowanych postaw moralnych. Jeśli chodzi o nauczycieli wychowania w domu, opiekunowie pełnią szereg funkcji społecznych (socjalizacja, adaptacja rehabilitacji, funkcje społeczno-kulturowe itd.), oraz wykonują tradycyjne obowiązki - uczą, kształcą, rozwijają.
\end{abstract}

Słowa kluczowe: wartość edukacji, edukacja w domu, indywidualne podejście, guwerner, trajektoria edukacyjna, rozwój, osobowość 